\title{
Behavioral and clinical characteristics of people receiving medical care for HIV infection in an outpatient facility in Sicily, Italy
}

This article was published in the following Dove Press journal:

Patient Preference and Adherence

25 May 2016

Number of times this article has been viewed

\author{
Paola Di Carlo' \\ Giuliana Guadagnino' \\ Palmira Immordino' \\ Giovanni Mazzola² \\ Pietro Colletti \\ Ilenia Alongi' \\ Lucia Adamoli' \\ Francesco Vitale' \\ Alessandra Casuccio' \\ 'Department of Sciences for Health \\ Promotion and Mother-Child Care \\ "G D'Alessandro", University of \\ Palermo, ${ }^{2}$ Department of Medicinal \\ Clinics and Emerging Diseases, "Paolo \\ Giaccone" Polyclinic University \\ Hospital, Palermo, Italy
}

Correspondence: Alessandra Casuccio Department of Sciences for Health Promotion and Mother-Child Care "G D’Alessandro", University of Palermo, Via del Vespro I27, 90127 Palermo, Italy

Tel +39916553929

Fax +39916553905

Email alessandra.casuccio@unipa.it
Aim: The authors examined a cohort of HIV-positive outpatients at the AIDS Center of Palermo University in Italy in order to identify factors related to the frequency of their visits to the outpatient facility for health care services.

Methods: Two hundred and twenty-four HIV-infected subjects were enrolled in the study. Demographic and HIV disease characteristics were recorded and assessed with the number of days accessed to our outpatients unit in univariate and multivariate analyses. The potential relationship with immunological status was also analyzed stratifying the patients into groups according to their CD4 ${ }^{+}$T-cell counts ( $\geq 500 \mathrm{vs}<500 / \mathrm{mm}^{3}$, and $\geq 200 \mathrm{vs}<200 / \mathrm{mm}^{3}$ ).

Results: Both univariate and multivariate analyses showed that duration of antiretroviral therapy $<5$ years and hypertension were significantly associated with a CD4 ${ }^{+} \mathrm{T}$-cell count of $<500 / \mathrm{mm}^{3}$, whereas geographic origin (Africa) was associated with a CD4 ${ }^{+} \mathrm{T}$-cell count of $<200 / \mathrm{mm}^{3}$. Mean number of days the patients sought access to day-care services for laboratory tests was negatively associated with $\mathrm{CD} 4^{+} \mathrm{T}$-cell count.

Conclusion: Patients with low $\mathrm{CD}^{+} \mathrm{T}$-cell counts showed higher use of health care services, demonstrating how early HIV diagnosis can help to reduce health care costs. The $\mathrm{CD}^{+} \mathrm{T}$-cell cut-off of 200 cells emphasizes the importance of identifying and managing HIV infection among hard-to-reach groups like vulnerable migrants. In our sample, the illegal status of immigrants does not influence the management of their HIV/AIDS condition, but the lack of European health card that documents the current antiretroviral status, could interfere with the efforts to eradicate AIDS. A better understanding of the major determinants of HIV treatment costs has led to appropriate large-scale actions, which in turn has increased resources and expanded intervention programs. Further guidance should be offered to hard-to-reach groups in order to improve early AIDS diagnosis, and procedures for identifying and managing these vulnerable subjects should be made available to care commissioners and service providers.

Keywords: HIV infection, CD4+ T-cell count, access to care, HIV outpatient service, hard-toreach groups, resource use

\section{Introduction}

The advent of antiretroviral therapy (ART) has effectively changed the clinical course of HIV and patient life expectancy. The 2013 Joint United Nations Programme on HIV and AIDS report estimated that 35 million people are living with HIV and 1.5 million have died of AIDS worldwide. ${ }^{1}$

The number of new infections, which is currently 2.1 million per year worldwide, is falling. ${ }^{1}$ However, because of socioeconomic reasons, there are discernible disparities between subequatorial countries and other parts of the world. This is 
demonstrated by differences in way and time of access to health care services in different countries. ${ }^{1}$

In Europe, access to health care is a key factor in promoting and safeguarding the individual's health. In Western and Northern Europe as well as in the US, preventing transmission of HIV infection and attempting early diagnosis have become the order of the day. However, since 2007, European health care systems have been affected by the global economic crisis, resulting in changes involving access to health care and to preventive services. The biggest challenge is how to provide optimal care for HIV patients at the lowest possible cost. In the US, the RESPECT program sponsored by the American Centers for Disease Control and Prevention has provided guidelines about the identification of patients whose risk factors justify carrying out anti-HIV testing, and about correct diagnostic and therapeutic procedures. The problem of migration, mainly from sub-Saharan Africa, is an issue with which many European countries and Italy and Spain are currently contending; this reality inevitably contributes to the significant change in HIV epidemiology. ${ }^{2-4}$

Migrants represent an independent risk factor for HIV infection, and at the same time, they are more likely to receive a delayed diagnosis due to late presentation with the disease. This makes clinical management more onerous and health care costs higher. In 2010, 49\% of new infections diagnosed in Europe were among migrants. The Dublin Declaration guarantees the right of citizens to ART. ${ }^{5,6}$

The delivery of health care services in Italy is patchy, and is financed and organized at a regional level; consequently, the cost of HIV treatment varies significantly across regions and between medical centers. In Southern Italy and in Sicily in particular, immigration can be considered an epidemiologically relevant phenomenon as far as health structures and institutional approaches are concerned, with an average of $\geq 24.1 / 100,000$ new HIV infections per year. ${ }^{7}$

In this study, we examined a cohort of HIV outpatients in Southern Italy between 2011 and 2013 in order to identify the factors that determined their utilization of health care resources. Consequently, we propose a way to better control the costs of managing these patients. We evaluated key factors by dividing the patients according to their $\mathrm{CD}^{+}$ T-cell counts.

\section{Materials and methods}

\section{Design and setting}

We conducted a retrospective study of $224 \mathrm{HIV}$-positive individuals who attended the Infectious Diseases Outpatient Clinic of the "Paolo Giaccone" University Hospital in Palermo,
Italy, for follow-up blood tests related to their HIV status between 2011 and 2013. Demographic and HIV disease characteristics were recorded and assessed with the number of days patients sought access to our outpatients unit in univariate and multivariate analyses. Potential relationship between immunological status was also analyzed stratifying the patients into groups according to their $\mathrm{CD}^{+} \mathrm{T}$-cell counts ( $\geq 500$ vs $<500 / \mathrm{mm}^{3}$ and $\geq 200$ vs $<200 / \mathrm{mm}^{3}$ ).

Approximately 700 patients are admitted to this clinic each year for HIV management. Committed to the prevention and care of HIV infection, it is the regional AIDS referral center. Between 2009 and 2013, 980 new cases of HIV infection were registered in Sicily (270 of these in Palermo), with an average incidence rate of 3.92/100,000 per year. ${ }^{8,9}$

Virological and immunological follow-up is performed every 3 or 6 months, depending on clinical and immunological parameters. Patients receive free comprehensive care, including treatment for opportunistic infections (including tuberculosis [TB]), macro- and micronutrient supplementation, psychosocial counseling, adherence counseling, and education about prevention strategies, and defaulter tracing is also carried out. According to Italian, European, and International guidelines, ${ }^{10}$ ART is typically initiated when $\mathrm{CD}^{+} \mathrm{T}$-cell count is $<350 / \mathrm{mm}^{3}$ (patients in clinical stage 3 or 4 ) and when $\mathrm{CD}^{+} \mathrm{T}$-cell count is $>350 / \mathrm{mm}^{3}$ but $<500 / \mathrm{mm}^{3}$. ART is recommended to prevent transmission, or in the event of pregnancy, coinfections (hepatitis B virus-hepatitis $\mathrm{C}$ virus [HBV-HCV], HIV-AN, $\mathrm{HIV}$-associated neurocognitive disorder [HAND]), or nonAIDS-related tumor. On the contrary, when $\mathrm{CD}^{+}{ }^{+} \mathrm{T}$-cell count is $>500 / \mathrm{mm}^{3}$, ART is recommended when there is a rapid decline in $\mathrm{CD}^{+} \mathrm{T}$-cell count $\left(\geq 100 / \mathrm{mm}^{3}\right.$ annually) or when the count of HIV-RNA is $\geq 100,000$ copies/mL. During each visit to the clinic, adherence is assessed by self-report. Adherence is considered "perfect" when the patients indicate that they have taken every dose as prescribed since starting ART.

Patient medical records were collected and entered into a hospital medical record database.

Informed consent, including consent to publication of patient details, was signed by all individuals before they accessed the day health care services, in accordance with the Declaration of Helsinki. The study protocol was approved by the Ethics Committee of the "Paolo Giaccone" University Hospital in Palermo, Italy.

\section{Patients}

Data on patients who were followed up at the AIDS Center of the "Paolo Giaccone" University Hospital in Palermo, Italy, in the day care or outpatient facility between January 2011 
and May 2013 were extracted from the hospital's medical record database.

We gathered clinical documentation on $224 \mathrm{HIV}$-positive subjects with complete follow-up data for the under-review period. The following data were collected and entered into the specially designed database: (a) demographic and clinical characteristics of patients: age, gender, geographic origin (namely patient's geographical origin stated in their document certified by the Italian institutions), lifestyle habits (including educational level, drug abuse history, sexual behavior), body mass index (BMI), comorbidities such as HCV coinfection, osteoporosis biomarker, treatment for dyslipidemia (total cholesterol $\geq 300 \mathrm{mg} / \mathrm{dL}$ and total cholesterol-to-high-density lipoprotein ratio $>5$ in males and $>4$ in females), diabetes, renal function, and hypertension; (b) current $\mathrm{CD}^{+} \mathrm{T}$ lymphocyte counts (cells $/ \mu \mathrm{L}$ ) were determined by flow cytometry, and HIV RNA viral load (VL) was measured in plasma by reverse transcriptase polymerase chain reaction (Roche Amplicor; lower limit of quantitation 20 copies/mL, $1.3 \log _{10}$ ) as previously reported; ${ }^{11}$ and (c) variables related to ART: date of ART initiation, total time on ART, antiretroviral (ARV) drugs received and degree of adherence, as well as protease inhibitors and non-nucleoside reverse transcriptase inhibitors, and exposure to tenofovir and other ARV drugs (ie, raltegravir, maraviroc). These data were obtained from medical records and previously published investigations. ${ }^{11-13}$

All patients except the treatment-naïve subjects had started ART during previous inpatient stays.

None of the migrants enrolled in the study had a general practitioner (GP).

\section{Statistical analysis}

Statistical analysis of quantitative and qualitative data, including descriptive statistics, was performed for all items. Continuous data are expressed as mean \pm standard deviation (SD), unless otherwise specified. Frequency analysis was performed with chi-square test or Fisher's exact test, as needed. The intergroup differences were assessed by one-way analysis of variance and Mann-Whitney $U$ statistic test for parametric and nonparametric variables, respectively.

Odds ratios (ORs) and their 95\% confidence intervals (CIs) were calculated using the univariate and multivariate model of multinomial logistic regression analysis. Data were analyzed with Epi Info software (version 6.0; Centers for Disease Control and Prevention, Atlanta, GA, USA) and IBM SPSS Software version 21.0 (IBM Corporation, Armonk, NY, USA). All $P$-values were two sided, and $P$-values $<0.05$ were considered statistically significant.

\section{Results}

Table 1 depicts the patient parameters collected from the electronic medical record database.

Data were stratified according to $\mathrm{CD}^{+}{ }^{+} \mathrm{T}$-cell count, comparing the characteristics of patients with $\mathrm{CD}^{+} \mathrm{T}$-cell counts $\geq 500$ vs $<500 / \mathrm{mm}^{3}$ and $\geq 200$ vs $<200 / \mathrm{mm}^{3}$. The average age of patients enrolled in the study was $45.6 \pm 9.2$ years; 163 were males $(73 \%)$, and 61 females (27\%); 26 outpatients were African immigrants (12\%) (Table 1). Nineteen of the 224 patients showed HIV-HCV coinfections $(8.5 \%)$ (Table 1). Fourteen patients were treatment-naïve $(6.3 \%)$, and the average of current $\mathrm{CD}^{+}$ T-cell count was 524 $292 \mathrm{SD}$ (median 476) $/ \mathrm{mm}^{3}$, while mean HIV RNA VL was $1.82( \pm 1.16$; median 1.3$) \log _{10}$ copies/mL.

For the whole group, mean number of days of access to day-care services for laboratory tests (to evaluate stage of HIV and to monitor treatment) was $6.5( \pm 2.5)$ days for $\mathrm{CD}^{+} \mathrm{T}$-cell count measurements and $9.6( \pm 3.5)$ for HIV RNA VL.

\section{$\mathrm{CD}^{+} \mathrm{T}$-cell count $\geq 500$ vs $<500 / \mathrm{mm}^{3}$}

For the patient groups with $\mathrm{CD}^{+} \mathrm{T}$-cell counts of $\geq 500$ vs $<500 / \mathrm{mm}^{3},<5$ years of ARV treatment and mean number of days of access to day-care services for laboratory tests - to evaluate HIV stage and to monitor treatment - were negatively associated with $\mathrm{CD}^{+}{ }^{+} \mathrm{T}$-cell count $(P=0.017$ and $P=0.026$, respectively) (Table 1; Figure 1).

As far as biochemical and physical parameters were concerned, hypertension was negatively associated with CD4 T-cell count in the $<500 / \mathrm{mm}^{3}$ group $(P=0.044)$ (Table 1$)$.

Table 2 depicts the univariate and multivariate regression analysis of patients with $\mathrm{CD}^{+} \mathrm{T}$-cell counts of $\geq 500$ vs $<500 / \mathrm{mm}^{3}$. Less than 5 years of ART $(\mathrm{OR}=2.01,95 \% \mathrm{CI}$ : $1.15-3.53, P=0.015$ and $\mathrm{OR}=2.21,95 \% \mathrm{CI}: 1.22-3.99$, $P=0.009$, respectively) and hypertension were significantly associated with a CD4 ${ }^{+} \mathrm{T}$-cell count of $<500 / \mathrm{mm}^{3}$ in both univariate and multivariate analyses $(\mathrm{OR}=2.20,95 \% \mathrm{CI}$ : 1.02-4.75, $P=0.044$ and $\mathrm{OR}=2.380,95 \% \mathrm{CI}: 1.05-5.41$, $P=0.039$, respectively).

Mean number of days of access to day-care services for laboratory tests was negatively associated with $\mathrm{CD} 4^{+} \mathrm{T}$-cell count but only in univariate regression analysis.

\section{$\mathrm{CD}^{+} \mathrm{T}$-cell count $\geq 200$ vs $<200 / \mathrm{mm}^{3}$}

We identified African race $(P=0.034)$, low BMI $(P=0.001)$, and drug addiction $(P=0.039)$ as significant risk factors in the $<200 / \mathrm{mm}^{3}$ patient group (Table 1 ). 


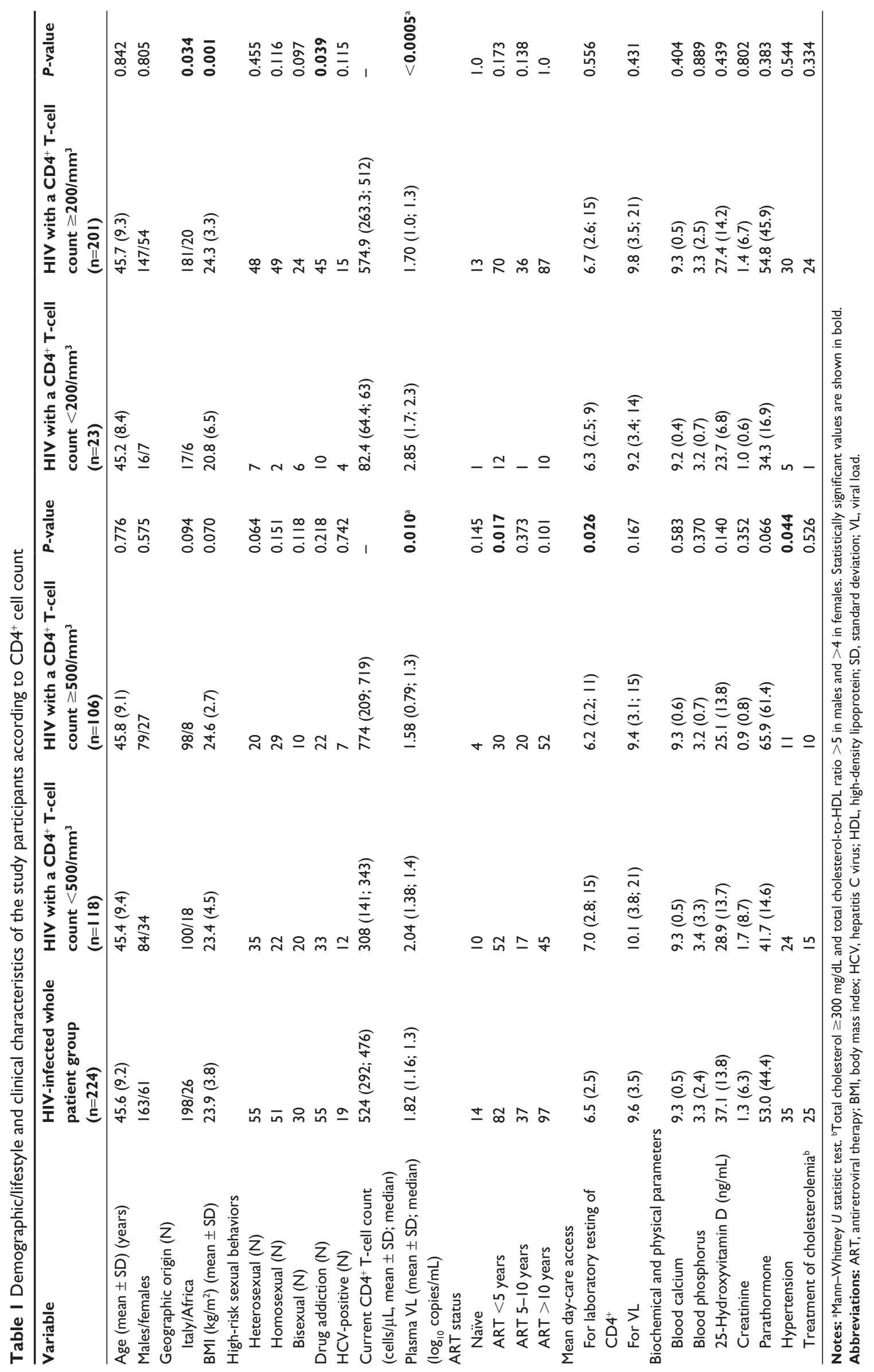




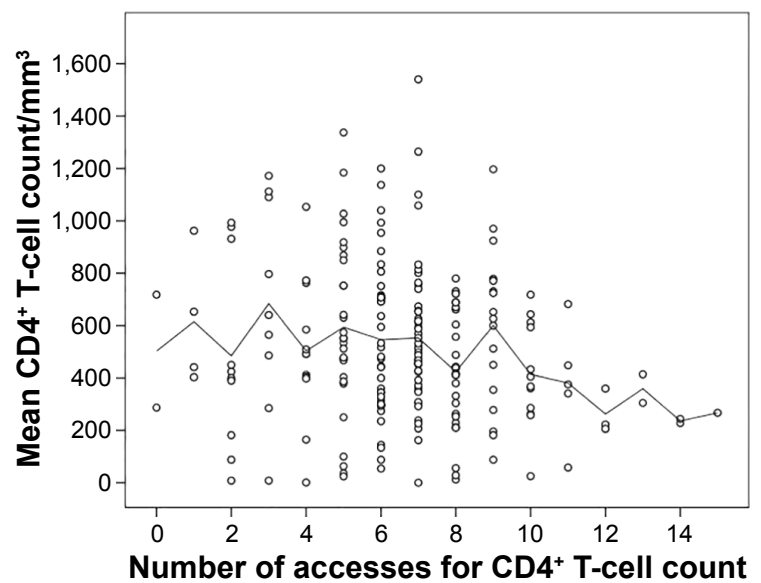

Figure I Number of days of accesses to the outpatients clinic according to CD4 T-cell count.

Table 3 depicts the univariate and multivariate regression analysis of patients with $\mathrm{CD}^{+} \mathrm{T}$-cell counts of $\geq 200$ vs $<200 / \mathrm{mm}^{3}$; we found a significant association between ethnicity (African) and a $\mathrm{CD}^{+} \mathrm{T}$-cell count of $<200 / \mathrm{mm}^{3}$ in both univariate and multivariate analyses $(\mathrm{OR}=3.19,95 \% \mathrm{CI}: 1.13-9.03, P=0.028$ and $\mathrm{OR}=10.05,95 \%$ CI: $1.84-54.9, P=0.008$, respectively), while a significant association between drug addiction and $\mathrm{CD}^{+}$count was detected in univariate regression analysis only (Table 3 ).

\section{Discussion}

The growing demand for health care services depends on a number of factors: an increase in the life expectancy of HIV patients, management of age-related diseases which requires patients to be monitored two to four times a year for highly active ART efficacy/toxicity, ethnicity and mode of transmission, AIDS-related diseases, and the important role of prevention (testing and counseling). ${ }^{12,14}$

The mean $\mathrm{CD}^{+} \mathrm{T}$-cell count of our patients was $524 / \mathrm{mm}^{3}$; therefore, we can consider them to be a well-managed population of individuals treated for HIV, with $\mathrm{CD} 4^{+}$cell counts over $500 / \mathrm{mm}^{3}$, or in any case, with chronic HIV infection and high $\mathrm{CD}^{+} \mathrm{T}$-cell levels.

Mean access to day-care services for laboratory tests to evaluate stage of HIV infection and to monitor treatment was 6.5 days for $\mathrm{CD}^{+}{ }^{+} \mathrm{T}$-cell count measurements and 9.6 for HIV RNA VL.

These results, which refer to a 25 -month follow-up period, comply with standard recommendations if we consider that

Table 2 Univariate and multivariate regression analysis of patients stratified by $500 / \mathrm{mm}^{3} \mathrm{CD} 4^{+}$T-cell count

\begin{tabular}{|c|c|c|c|c|c|c|}
\hline & \multicolumn{6}{|c|}{ HIV with a CD4 $4^{+}$T-cell count $<500$ vs $\geq 500 / \mathrm{mm}^{3}$} \\
\hline & \multicolumn{3}{|c|}{ Univariate } & \multicolumn{3}{|c|}{ Multivariate } \\
\hline & $\operatorname{Exp}(B)$ & $95 \% \mathrm{Cl}$ & $P$-value & $\operatorname{Exp}(B)$ & $95 \% \mathrm{Cl}$ & $P$-value \\
\hline \multicolumn{7}{|l|}{ Demographic/lifestyle characteristics } \\
\hline Age & 0.996 & $0.97-1.02$ & 0.775 & & & \\
\hline Female gender & 1.20 & $0.66-2.16$ & 0.549 & & & \\
\hline Nationality & 2.205 & $0.92-5.30$ & 0.078 & & & \\
\hline BMI & 0.910 & $0.82-1.01$ & 0.083 & & & \\
\hline \multicolumn{7}{|l|}{ Characteristics of HIV infection } \\
\hline Naïve ART & 2.847 & $0.82-9.87$ & 0.099 & & & \\
\hline Homosexual & 0.608 & $0.32-1.14$ & 0.122 & & & \\
\hline Bisexual & 1.959 & $0.87-4.40$ & 0.103 & & & \\
\hline Heterosexual & 1.813 & $0.97-3.39$ & 0.063 & & & \\
\hline \multicolumn{7}{|l|}{ ART } \\
\hline$<5$ years & 2.013 & $1.15-3.53$ & 0.015 & 2.206 & $1.22-3.99$ & 0.009 \\
\hline $5-10$ years & 0.719 & $0.35-1.46$ & 0.362 & & & \\
\hline$>10$ years & 0.627 & $0.36-1.08$ & 0.090 & & & \\
\hline Drug addiction & 1.482 & $0.80-2.75$ & 0.212 & & & \\
\hline Number of accesses for VL & 1.056 & $0.98-1.14$ & 0.167 & & & \\
\hline Number of accesses for $\mathrm{CD}^{+}$ & 1.128 & $1.02-1.26$ & 0.028 & 1.092 & $0.98-1.22$ & 0.130 \\
\hline $\mathrm{CO}-\mathrm{HCV}$ & 1.601 & $0.6 I-4.23$ & 0.342 & & & \\
\hline \multicolumn{7}{|l|}{ Biochemical and physical parameters } \\
\hline Blood calcium & 0.860 & $0.50-1.47$ & 0.582 & & & \\
\hline Blood phosphorus & 1.076 & $0.89-1.30$ & 0.446 & & & \\
\hline 25-Hydroxyvitamin $\mathrm{D}(\mathrm{ng} / \mathrm{mL})$ & 1.021 & $0.99-1.05$ & 0.142 & & & \\
\hline Creatinine & 1.042 & $0.91-1.20$ & 0.567 & & & \\
\hline Parathormone & 0.980 & $0.95-1.01$ & 0.149 & & & \\
\hline Hypertension & 2.205 & $1.02-4.75$ & 0.044 & 2.380 & $1.052-5.4 \mathrm{I}$ & 0.039 \\
\hline Treatment of cholesterolemia & 1.398 & $0.60-3.26$ & 0.438 & & & \\
\hline
\end{tabular}

Note: Statistically significant values are shown in bold.

Abbreviations: ART, antiretroviral therapy; BMI, body mass index; $\mathrm{Cl}$, confidence interval; VL, viral load; CO-HCV, HIV-HCV coinfections. 
Table 3 Univariate and multivariate regression analysis of patients' characteristics stratified by $200 / \mathrm{mm}^{3} \mathrm{CD}^{+}{ }^{+} \mathrm{T}_{\text {-cell count }}$

\begin{tabular}{|c|c|c|c|c|c|c|}
\hline & \multicolumn{6}{|c|}{ HIV with a CD4 ${ }^{+}$T-cell count $<200$ vs $\geq 200 / \mathrm{mm}^{3}$} \\
\hline & \multicolumn{3}{|c|}{ Univariate } & \multicolumn{3}{|c|}{ Multivariate } \\
\hline & $\operatorname{Exp}(B)$ & $95 \% \mathrm{Cl}$ & $P$-value & $\operatorname{Exp}(B)$ & $95 \% \mathrm{Cl}$ & $P$-value \\
\hline \multicolumn{7}{|l|}{ Demographic/lifestyle characteristics } \\
\hline Age & 0.995 & $0.95-1.04$ & 0.841 & & & \\
\hline Female gender & 1.18 & $0.46-3.03$ & 0.727 & & & \\
\hline Ethnicity & 3.194 & $1.13-9.03$ & 0.028 & 10.052 & $1.84-54.9$ & 0.008 \\
\hline $\mathrm{BMI}$ & 0.854 & $0.75-0.97$ & 0.014 & 1.080 & $0.94-1.24$ & 0.267 \\
\hline \multicolumn{7}{|l|}{ Characteristics of HIV infection } \\
\hline Naïve ART & 0.663 & $0.08-5.76$ & 0.710 & & & \\
\hline Homosexual & 0.295 & $0.07-1.31$ & 0.108 & & & \\
\hline Bisexual & 2.603 & $0.94-7.25$ & 0.067 & & & \\
\hline Heterosexual & 1.395 & $0.54-3.59$ & 0.491 & & & \\
\hline \multicolumn{7}{|l|}{ ART } \\
\hline$<5$ years & 0.522 & $0.22-1.24$ & 0.142 & & & \\
\hline $5-10$ years & 0.198 & $0.03-1.52$ & 0.119 & & & \\
\hline$>10$ years & 0.937 & $0.39-2.24$ & 0.884 & & & \\
\hline Drug addiction & 2.667 & I.10-6.49 & 0.031 & 3.959 & $0.79-19.8$ & 0.094 \\
\hline Number of accesses for VL & 0.951 & $0.84-1.08$ & 0.429 & & & \\
\hline Number of accesses for $\mathrm{CD}^{+}$ & 0.950 & $0.80-1.13$ & 0.554 & & & \\
\hline $\mathrm{CO}-\mathrm{HCV}$ & $2.6 \mathrm{II}$ & $0.79-8.67$ & 0.117 & & & \\
\hline \multicolumn{7}{|l|}{ Biochemical and physical parameters } \\
\hline Blood calcium & 0.656 & $0.25-1.74$ & 0.397 & & & \\
\hline Blood phosphorus & 0.984 & $0.78-1.24$ & 0.890 & & & \\
\hline 25-Hydroxyvitamin $D(\mathrm{ng} / \mathrm{mL})$ & 0.979 & $0.93-1.04$ & 0.435 & & & \\
\hline Creatinine & 0.985 & $0.87-1.12$ & 0.815 & & & \\
\hline Parathormone & 0.949 & $0.87-1.04$ & 0.228 & & & \\
\hline Hypertension & 1.583 & $0.55-4.59$ & 0.397 & & & \\
\hline Treatment of cholesterolemia & 0.335 & $0.04-2.60$ & 0.296 & & & \\
\hline
\end{tabular}

Note: Statistically significant values are shown in bold.

Abbreviations: ART, antiretroviral therapy; BMI, body mass index; $\mathrm{Cl}$, confidence interval; VL, viral load; $\mathrm{CO}-\mathrm{HCV}, \mathrm{HIV}-\mathrm{HCV}$ coinfections.

our cohort consists of patients who are on ART and have undetectable VL levels. Regarding mean and standard deviation calculated for the number of days of access to health care services for VL monitoring, our data demonstrate the importance of ARV drug monitoring and management to assess indicators such as adherence and emergence of HIV drug resistance, and to estimate the time to viral suppression after initiating a first-line regimen. ${ }^{15,16}$

In our study, mean number of days of access to day care for laboratory tests was negatively associated with $\mathrm{CD} 4^{+}$ cell counts. These findings provide further support for early combination ART initiation in order to reduce the costs of health care management. ${ }^{17,18}$

Stratifying the patients according to $\mathrm{CD} 4{ }^{+} \mathrm{T}$-cell count, the $500 / \mathrm{mm}^{3}$ cut-off value helps us to identify the factors that determine manner and time of access to health care for HIV patients, whereas the $200 / \mathrm{mm}^{3}$ cut-off shows the key high-risk HIV groups such as migrants vs natives and drug addiction categories and confirmed the higher frequency of AIDS events in these categories of patients, as reported in other studies and recently by the Italian ICONA cohort study group..$^{19,20}$
Regarding patient comorbidities, only hypertension was significantly associated with $\mathrm{CD} 4^{+} \mathrm{T}$-cell count, highlighting how we can identify the key factors that determine HIV patients' use of health care services through monitoring other pathologies affecting these subjects, such as cardiovascular disease. ${ }^{21}$

But how are we to cope with increased demand for these health care resources in a time of economic crisis?

Our study demonstrates that two categories of patients drug addicts and immigrants - make greater use of health care services.

Data on injection drug users per se emphasize the importance of sustained HIV prevention measures for this category of patients who generally have a poor prognosis..$^{22-24}$

Nevertheless, we must stress the importance of managing the migrant population if we aim to reduce health care costs related to HIV infection.

Patients in the "frail patient" category and those with sociopsychological issues are most in need of health care. In particular, the influx of immigrants poses a real challenge to public health, other than a significant change in HIV 
epidemiology. Available literature shows that utilization of health care services is a primary indicator of migrant integration. ${ }^{25}$

None of the migrants enrolled in the study had a GP, though some of them had been resident in the country for a long time. Generally speaking, not only migrants but also Italian natives are reluctant to go to their GP. The Italian National Health Systems are going through a phase of change, but patients still prefer to go to hospital rather than visit their GP. This has been found in a pediatric study that the first author has published. ${ }^{26}$

Many of the immigrant patients in the study had just arrived from Libya in a situation of humanitarian emergency, as continues to be the case today. They are then transferred to a migrant reception center where they do not have access to a GP. Even after being in the country for some time, because of their frequent lack of work, they are considered illegal immigrants. Moreover, without a permit to stay in the country, they cannot be assigned to a GP. Regarding the services we provide for these migrants, we want to stress that their status has never influenced ART decisions. Thanks to an exemption granted by the Italian state, these individuals receive the same treatment as Italian natives regardless of cost and based solely on the patient's state of health. Unfortunately, because there is no European health card for migrants, data about treatment that these patients received in other countries once they had started ART are not available. The same may be said for other pathologies such as TB. Today, data need to be updated to take into account the emergency in Syria, but in general, the incidence of AIDS among African subjects remains high, as the incidence of TB does.

The findings of this study have several limitations. First, we did not determine $\mathrm{CD}^{+}$nadir, so we cannot correct the data with other risk factors, and we cannot estimate the time passed from the first diagnosis and the beginning of ARV even if none of migrant population and most of Italian HIV patients had never had a $\mathrm{CD}^{+}$count before admission to our hospital. Second, our study shows all the limitations of retrospective studies, and the small number of patients could suggest that our data reflected a local epidemiological situation.

The Italian government recognizes that migrants are vulnerable to social stigma, lack of community support, isolation, racism, and discrimination for being an HIV-positive migrant. Nevertheless, HIV testing for migrants is not explicitly recommended in Italy. For this reason, from 2009 to 2013, the ARTEMIS project was established to provide a program of social and health integration. COA-ISS data show an increase in the rate of new HIV infections among migrants compared to 1996, and a higher incidence of TB-HIV coinfection (particularly in patients from Eastern Europe). ${ }^{27,28}$

Total delay in diagnosis and initiation of effective treatment depends on two separate, but in some cases concomitant, elements: the delay attributable to the patient and the delay attributable to the health care system.

Delay attributable to the patient may be due to many factors, including demographics (gender, age), level of education, socioeconomic factors (poverty, loss of income or employment), awareness of the symptoms of disease, logistic factors (accessibility of health services, the structure chosen for first login), stigma associated with infectious disease, and in some populations, cultural and/or religious bias.

Delay attributable to the health care system depends on organizational aspects, such as weaknesses in the service network, lack of coordination and lack of effective and timely flow of information, lack of awareness of the clinical problem within the service network, or infrequent use of rapid diagnostic tools. A "vicious cycle" of repeated access to the same structure or structures of the same level with little diagnostic capacity is one of the main risk factors for delayed diagnosis.

Scientific evidence shows that in countries with a low incidence of the disease, the presence of problematic, vulnerable, and socially marginalized groups is a determining factor of delays in diagnosis and in initiating appropriate treatment, and may represent an epidemiologically relevant source of HIV transmission.

Migrants and refugees from countries with a high incidence of HIV and other coinfections such as TB are exposed to difficulties related to language and cultural barriers, especially in the early years of their stay in Italy; these factors constitute a substantial part of the so-called vulnerable communities. ${ }^{29,30}$

Sicily's regional health policy lacks the involvement of cultural associations that can raise awareness and direct migrants to preventive health care services. Most of the immigrants diagnosed with HIV are pregnant women who have undergone tests for sexually transmitted diseases. The delay in diagnosis together with the difficulty of access to preventive health care services may mean that these patients at diagnosis exhibit other HIV-related diseases resulting in a strong burden for the health care system. ${ }^{27,31}$

\section{Conclusion}

A better understanding of the major determinants of HIV treatment costs has led to appropriate large-scale actions, 
which has increased resources and expanded intervention programs. As is the case for TB, further guidance needs to be offered to hard-to-reach groups in order to diagnose AIDS earlier, ${ }^{32,33}$ and procedures for identifying and managing these vulnerable subjects should be made available to care commissioners and service providers. ${ }^{34}$

\section{Acknowledgment}

The authors wish to thank Fanny Pojero, $\mathrm{PhD}$, for reviewing the language and the syntax of the manuscript.

\section{Disclosure}

The authors declare that there is no conflict of interests regarding the publication of this paper.

\section{References}

1. Global report: UNAIDS report on the global AIDS epidemic 2013. "UNAIDS/JC2502/1/E" - revised and reissued. 2013. Available from: http://www.unaids.org/sites/default/files/en/media/unaids/contentassets/documents/epidemiology/2013/gr2013/UNAIDS_Global_ Report_2013_en.pdf. Accessed February 27, 2015.

2. Mugavero MJ, Davila JA, Nevin CR, Giordano TP. From access to engagement: measuring retention in outpatient HIV clinical care. AIDS Patient Care STDS. 2010;24:607-613.

3. Catania JA, Dolcini MM, Gandelman AA, Narayanan V, McKay VR. Fiscal loss and program fidelity: impact of the economic downturn on HIV/STI prevention program fidelity. Transl Behav Med. 2014;4: 34-45.

4. Oliva J, Díez M, Galindo S, et al. Predictors of advanced disease and late presentation in new HIV diagnoses reported to the surveillance system in Spain. Gac Sanit. 2014;28:116-122.

5. Hoyos J, Fernández-Balbuena S, de la Fuente L, et al; Madrid Rapid HIV Testing Group. Never tested for HIV in Latin-American migrants and Spaniards: prevalence and perceived barriers. J Int AIDS Soc. 2013; $16: 18560$

6. ECDC - migrants monitoring implementation of the Dublin Declaration on Partnership to fight HIV/AIDS in Europe and Central Asia: 2012 progress report. Available from: http://ecdc.europa.eu/en/publications/ Publications/dublin-migrants-evidence-brief-september-2013.pdf. Accessed February 27, 2015.

7. Update new diagnostic is HIV infection and cases of AIDS in Italy at 31 December 2011. Available from: http://www.iss.it/binary/ccoa/cont/ Report_COA_2012_corretto.pdf. Accessed February 27, 2015.

8. Surveillance of HIV in Sicily, Italy - 2013. Available from: http:// pti.regione.sicilia.it/portal/page/portal/PIR_PORTALE/PIR_ LaStrutturaRegionale/PIR_AssessoratoSalute/PIR_AreeTematiche/ PIR_Epidemiologia/PIR_Registridipatologia/PIR_RegistrosorveglianzaHIV/Report_HIV_2014.pdf. Accessed February 27, 2015.

9. Camoni L, Boros S, Regine V, et al. Aggiornamento delle nuove diagnosi di infezione da HIV e dei casi di AIDS in Italia al 31 dicembre 2013 [Update of new diagnoses of HIV infection and AIDS cases in Italy on 31 December 2013]. Not Ist Super Sanità. 2014;27(9 Suppl 1): 3-47. Italian.

10. Panel on Antiretroviral Guidelines for Adults and Adolescents. Guidelines for the use of antiretroviral agents in HIV-1-infected adults and adolescents. Department of Health and Human Services. Available from: http://www.aidsinfo.nih.gov/ContentFiles/AdultandAdolescentGL.pdf. Accessed April 27, 2016.

11. Li Vecchi V, Soresi M, Giannitrapani L, et al. Dairy calcium intake and lifestyle risk factors for bone loss in hiv-infected and uninfected Mediterranean subjects. BMC Infect Dis. 2012;12:192.
12. Restelli U, Andreoni M, Antinori A, et al. Budget impact analysis of antiretroviral less drug regimen simplification in HIV-positive patients on the Italian National Health Service. Clinicoecon Outcomes Res. 2014; 6:409-414.

13. Li Vecchi V, Giannitrapani L, Di Carlo P, et al. Non-invasive assessment of liver steatosis and fibrosis in $\mathrm{HIV} / \mathrm{HCV}$ - and $\mathrm{HCV}$-infected patients. Ann Hepatol. 2013;12:740-748.

14. Rizzardini G, Bonfanti P, Carenzi L, et al. Cost-effectiveness analysis of HIV treatment in the clinical practice of a public hospital in northern Italy. Ther Clin Risk Manag. 2012;8:377-384.

15. World Health Organization (WHO). National AIDS programmes: a guide to indicators for monitoring and evaluating national antiretroviral programmes. Geneva: WHO; 2006. Available from: http://www. who.int/hiv/en. Accessed February 27, 2015.

16. World Health Organization (WHO). Patient monitoring guidelines for HIV care and antiretroviral therapy (ART). Geneva: HIV/AIDS Department, WHO; 2008. Available from: http://www.who.int/hiv/pub/guidelines/ patientmonitoring.pdf. Accessed February 27, 2015.

17. Sidibé M, Zuniga JM, Montaner J. Leveraging HIV treatment to end AIDS, stop new HIV infections, and avoid the cost of inaction. Clin Infect Dis. 2014;59 Suppl 1:S3-S6.

18. WHO. Consolidated Guidelines on the Use of Antiretroviral Drugs for Treating and Preventing HIV Infection: Recommendations for a Public Health Approach. Geneva: World Health Organization; 2013.

19. Saracino A, Lorenzini P, Lo Caputo S, et al; ICONA Foundation Study Group. Increased risk of virologic failure to the first antiretroviral regimen in HIV-infected migrants compared to natives: data from the ICONA cohort. Clin Microbiol Infect. 2016;22:288.e1-288.e8.

20. Pezzoli MC, Hamad IE, Scarcella C, et al; PRISHMA Study Group. HIV infection among illegal migrants, Italy, 2004-2007. Emerg Infect Dis. 2009;15:1802-1804.

21. Brennan A, Morley D, O'Leary AC, Bergin CJ, Horgan M. Determinants of HIV outpatient service utilization: a systematic review. AIDS Behav. 2014;19:104-119.

22. Milloy MJ, Marshall BD, Kerr T, et al. Social and structural factors associated with HIV disease progression among illicit drug users: a systematic review. AIDS. 2012;26:1049-1063.

23. Booth RE, Dvoryak S, Sung-Joon M, et al. Law enforcement practices associated with HIV infection among injection drug users in Odessa, Ukraine. AIDS Behav. 2013;17:2604-2614.

24. Camoni L, Raimondo M, Regine V, Salfa MC, Suligoi B; regional representatives of the HIV Surveillance System. Late presenters among persons with a new HIV diagnosis in Italy, 2010-2011. BMC Public Health. 2013;13:281.

25. Wasserfallen JB, Hyjazi A, Cavassini M. Comparison of HIV-infected patients' characteristics, healthcare resources use and cost between native and migrant patients. Int J Public Health. 2009;54:5-10.

26. Di Carlo P, Romano A, Plano MR, et al. Children, parents and Respiratory Syncytial Virus in Palermo, Italy: prevention is primary. $J$ Child Health Care. 2010;14:396-407.

27. Alvarez-Del Arco D, Monge S, Caro-Murillo AM, et al; Study Working Group. HIV testing policies for migrants and ethnic minorities in EU/ EFTA Member States. Eur J Public Health. 2014;24:139-144.

28. ARTEMIS: Associations \& Territorial Networks for Intercultural Mediation Health. Available from: http://www.iss.it/ccoa. Accessed February 27, 2015.

29. Sulis G, El Hamad I, Fabiani M, et al; HIV/Migrants Study Group. Clinical and epidemiological features of HIV/AIDS infection among migrants at first access to healthcare services as compared to Italian patients in Italy: a retrospective multicentre study, 2000-2010. Infection. 2014;42:859-867.

30. Diez M, Diaz A, Garriga C, et al; The Hospital Survey Study Group C. A low-cost, sustainable, second generation system for surveillance of people living with HIV in Spain: 10-year trends in behavioural and clinical indicators, 2002 to 2011. Euro Surveill. 2014;19(20).

31. Pellowski JA, Kalichman SC. Recent advances (2011-2012) in technology-delivered interventions for people living with HIV. Curr HIV/AIDS Rep. 2012;9:326-334. 
32. Seedat F, Hargreaves S, Friedland JS. Engaging new migrants in infectious disease screening: a qualitative semi-structured interview study of UK migrant community health-care leads. PLoS One. 2014;9(10): e108261.

33. Mirzazadeh A, Grasso M, Johnson K, et al. Acceptability of Global Positioning System technology to survey injecting drug users' movements and social interactions: a pilot study from San Francisco, USA Technol Health Care. 2014;22:689-700.
34. Mocroft A, Lundgren JD, Sabin ML, et al; Collaboration of Observational HIV Epidemiological Research Europe (COHERE) study in EuroCoord. Risk factors and outcomes for late presentation for HIVpositive persons in Europe: results from the Collaboration of Observational HIV Epidemiological Research Europe Study (COHERE). PLoS Med. 2013;10(9):e1001510.

\section{Publish your work in this journal}

Patient Preference and Adherence is an international, peer-reviewed, open access journal that focuses on the growing importance of patient preference and adherence throughout the therapeutic continuum. Patient satisfaction, acceptability, quality of life, compliance, persistence and their role in developing new therapeutic modalities and compounds to optimize clinical outcomes for existing disease states are major areas of interest for the journal. This journal has been accepted for indexing on PubMed Central. The manuscript management system is completely online and includes a very quick and fair peer-review system, which is all easy to use. Visit http://www. dovepress.com/testimonials.php to read real quotes from published authors.

\footnotetext{
Submit your manuscript here: http://www.dovepress.com/patient-preference-and-adherence-journal
} 